\title{
History of origin and development, compositional and morphological features of park pavilions in Ancient China
}

\author{
Yulia Ivashko ${ }^{1}$, Dominika Kuśnierz-Krupa ${ }^{2}$, Chang Peng ${ }^{3}$ \\ ${ }^{1,3}$ Kyiv National University of Construction and Architecture, Ukraine \\ ${ }^{2}$ Cracow University of Technology, Poland
}

\begin{abstract}
The article analyses the origins of such a small architectural form as the Chinese pavilion, investigates its functional, planning and artistic figurative features. The evolution of functional and artistic figurative solution of pavilions from dynasty to dynasty is determined. On the basis of the dimensions of the preserved pavilions, their proportional and metro-rhythmic features were determined; a list of the most characteristic forms of roofs as the main exponents of the national originality of the Chinese pavilions was compiled. The reasons for the revival of the tradition of "chinoiserie" style in modern landscape design are argued.
\end{abstract}

Keywords: Chinese architecture, pavilions, gazebos, multi-functionality, revival of traditions

\section{Introduction}

The relevance of the topic of study of small architectural forms of China, known in Chinese scientific sources as the "pavilion", and in the postSoviet space as "gazebo", is due to the fact that over the past decades, there has been a revival of the trend of the design of small architectural forms and landscapes "in Chinese style" [13]. There are several reasons for this: the rapid development of the People's Republic of China and its entry into the world market as a powerful economically developed country, the increase in the share of Chinese goods in the market of the world countries, the greater openness of China to tourists, the search of ways of harmony with nature as a counterbalance to the forwardness of industrialization, the need to create one's own space for aesthetic solitude, etc. Today, many companies offer customized and typical "Chinese style" gazebos and landscaping projects; however, such contemporary gazebos are by no means a literal repetition of ancient designs.

In the life of a European or American, a gazebo does not play such an important role as a garden or city pavilion in China, where it performed a much broader range of functions than the modern stylized gazebo now performs (Fig. 1). It should be noted that the construction of pavilions in China was at all times under control of the authorities, even treatises were issued describing the rules for the construction of pavilions, which were different in cities, imperial residences, villages, monasteries or in the natural environment; in addition, they were built on the principles of Feng dhui and display some hidden content, the purpose of the building and the social status of the owner.
The pavilion in China has long been the quintessence of national forms and cultural and artistic preferences, a kind of microcosm of Chinese design, primarily due to the spread of this type of buildings throughout China (Fig. 2).

Traditional Chinese architecture has become the topic of many scientific sources $[1 ; 2 ; 4 ; 5 ; 7 ; 8 ; 9 ; 10$; $11 ; 12]$. This topic is directly related to the theme of European "Chinese style" stylizations, in particular, the specific features of "chinoiserie" style [12] and the revival of Chinese motifs in contemporary landscape design [13]. At the same time, most of the sources focus on urban planning, palace complexes, temple structures, rather than a comprehensive study of small architectural forms such as pavilions. Even the thematic monograph dedicated specifically to pavilions of different dynasties, presents mainly historical references, architectural descriptions, chronological table of evolution of the pavilion type and extensive illustrated material - photos and dimensional drawings [4; 7]. These drawings became the basis for deepening the study and analysis of compositional construction, morphology of the basic forms, and planning.

Another possible area of research is the comparison of the compositional and planning techniques of Chinese pavilions and European gazebos, pavilions and buildings of the 18th-19th centuries in "Chinese style" for the purpose of arguing exactly how the modification and transformation of individual chinoiserie forms occurred [12].

Authors used some scientific methods, such as the method of historical analyse, the method of comparative analyse, the graphic and analytical method, the method of the systematic-structural 


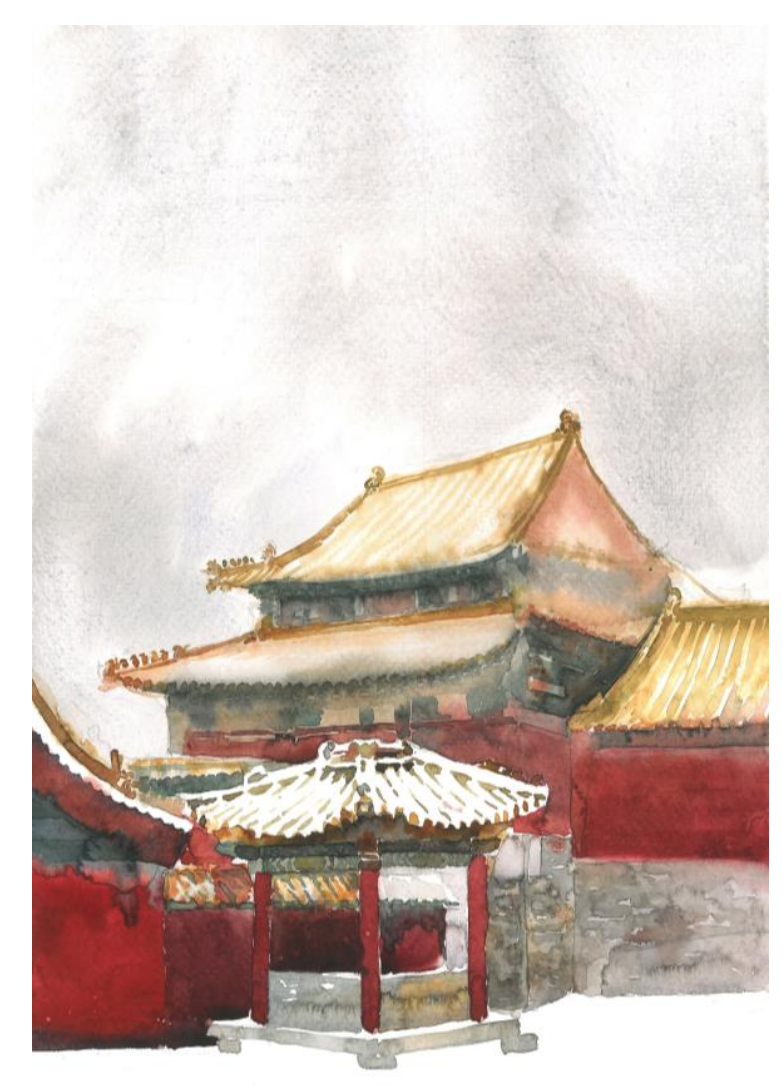

Fig. 1. Pavilion-gazebo near the Thai Hoa building of Gùgōng Palace in Beijing.

Watercolour by Chang Peng, 2019.

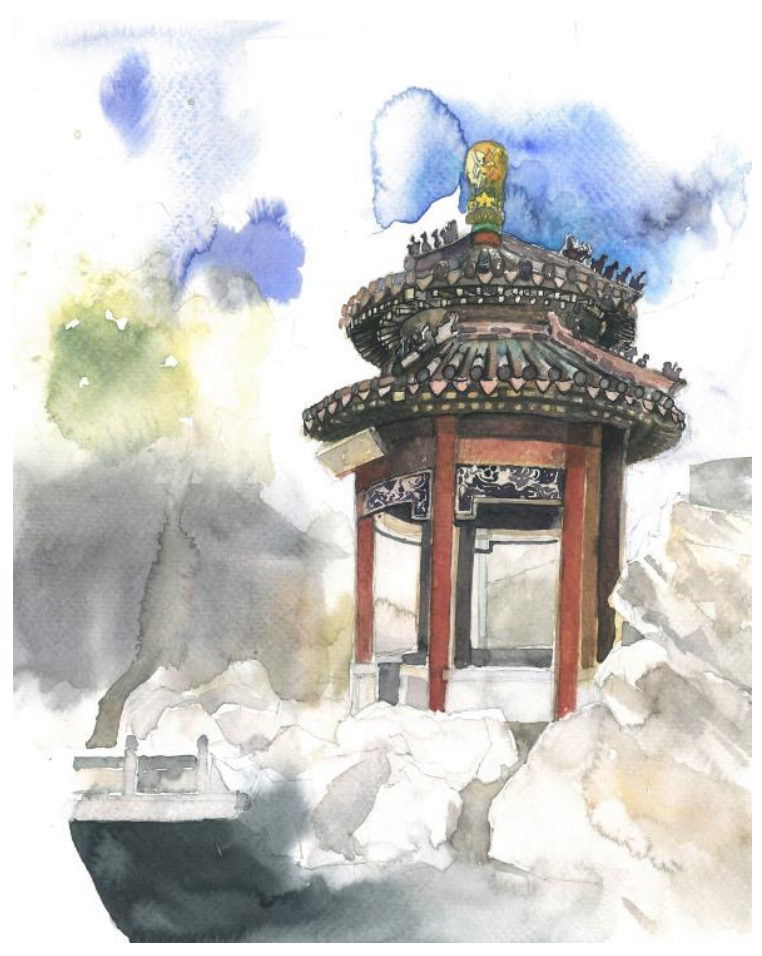

Fig. 2. Biluo Pavilion, Qianlong Garden of Forbidden City, Beijing. Watercolour by Chang Peng, 2019.

analyse. On the basis of the historical analyse studied origins of Chinese pavilions and gazebos, using the method of comparative analyse made possible to compare the location of objects in the natural environment, the feature of their composition and plans. The graphic and analytical method made possible to compare the drawings of the historical pavilions and gazebos. Method of the systemstructural analysis made it possible to establish the principles of location Chinese pavilions and gazebos of in the natural and urban environment, typical planning schemes, the main features of architecture of different historical periods.

\section{Evolution of a Chinese pavilion: \\ from military guard duty to hedonistic function}

Although China's pavilions are mostly referred to Shang (1600-1046 BC) and Zhou (1046-256 (221) BC) dynasties, the origins of this type of structures should be sought in earlier times, as well as in the Spring and Summer Dynasties (771-476 BC) and Warring States period (403-256 BC). It is believed that pavilion prototypes appeared before Qin dynasty (221-206 BC), and during the reign of Qin and Han dynasties (206 BC-220 AD), these were rather simple pavilions with flexible function $[4,6,8]$.

During the reigns of the Spring and Summer Dynasties and Warring States period, pavilions were essentially small fortresses on the borders, on outposts, at trenches, that is, they had a purely strategic purpose. Subsequently, in Qin and Han epochs, administrative and controlling functions were added to the military function, since the pavilions began to perform the function of management, as did other administrative buildings [4, 6, 8]. Emperor Liu Bang from Han dynasty was appointed a Chief Officer of Sishui Pavilion [4, 6, 8].

The rulers of Han dynasty continued the tradition of the rulers of Qin dynasty and built pavilions every ten "li", so according to the general census throughout the country, there were 29,635 pavilions. The semantics of the word "pavilion" initially meant literally "standing", and only later this meaning turned into "place for temporary housing" and "place to stay"; during Han era, pavilions began to be used to communicate an artificially created architectural environment with beautiful natural surroundings. Sbuo Wen called a pavilion a multilevel structure on a high place, and the approximate appearance of the pavilions of that time can be represented by the corresponding hieroglyphs $[4,6,8]$. The rock fresco images by Mogao of Tang era (618-907 AD) can characterize the state of development of small architectural forms of 
this period: pavilions are marked by a variety of outlines of roofs (acute-angled conical, hipped, with double eaves).

During the period of the Northern Qi dynasty (550-577 BC) in Jinci Temple at the headwaters of the Jinshui River, the Spring Pavilion Nanlao was constructed; later this original pavilion on an orthogonal (octagonal) plane with a pointed rectangular conical roof, cantilevered leads and slightly centrally inclined columns was reconstructed in the period of Ming dynasty (1368-1644 BC). Jiu Zhang Suan Shu, who lived in the period of Eastern Han dynasty (25-220 AD), considered all cubic platforms to be pavilions, square pavilions stood on a quadrangular platform, and round ones - on a circular platform. It is during Han era that the architectural modification of the type of pavilion occurs, which becomes a tiered structure of bars and beams on the platform, and each pavilion receives a separate name, due to the function and location. Pavilions above the city gates were called pavilions with the flag, in the market market pavilions, in the administrative section - city pavilions, at the borders - border pavilions, where the functions of the tiered structure were just reduced to the observation of the surroundings and the implementation of signaling functions.

Beginning with Wei (200-266 AD) and Jin dynasties (265-420 AD), the society rethinks the function of the pavilion, and the function of aesthetic enjoyment of merger with a natural environment comes to the fore. A typical example is the Orchid Pavilion, on the northern slope of Kuaiji Mountain, which initially served as a postal roadside pavilion, and later was twice ported for a better view, first to the shore of the lake, then to the top of the hill for a better view $[4,6,12]$.

However, these were not traditional garden pavilions. The first mention of the garden pavilions is found in the Northern Wei dynasty in the manuscripts of Yang Xuan and Li Daoyuan, in particular, the latter describes the Pavilion on the Stream in the garden Hualin $[4,6,12]$. Garden pavilions become especially popular in the era of the Southern dynasty. In the Imperial Garden of Emperor Yuan from Liang dynasty (502-557 AD) there were pavilions with the poetic names of Yinshi Ting (Hermit Pavilion), Yingyue Ting (Moon Pavilion), Linfeng Ting (Pavilion by the Wind).

In fact, since the time of Song and Tand dynasties, pavilions have occupied an important place in gardens and parks. Records of Daye Era (605-618 AD), during the reign of Emperor Yang of Sui dynasty, mention twelve pavilions in the mountains, Cuiwei Pavilion in the Imperial Palace and Happiness Pavilion in the Emperor's garden, which was regarded by contemporaries as a styles, plans (square, hexa- and octagonal, round), masterpiece worthy of a place in history [4, 13]. At that time, there were 24 pavilions in the Imperial Palace, 18 of them in the garden. Subsequently, in Tan era Tan (618-907 AD), the imperial fad gave impulse to the mass erection of such garden pavilions with poetic names in noble estates and monasteries across the country.

During the reign of Song dynasty (960-1279 AD), the development of the architectural and structural system of the pavilions and their functions continued; treatises devoted to their design and a list of standardized forms appeared during this period. There is a focus on building a connection with the natural environment. During Ming (1368-1644 AD) and Qing era (1644-1912 AD), purposes of landscape design expanded to include pavilions, and attention was paid not only to the pavilion's architecture, but also to the choice of location, landscape environment, and conformity of architecture and nature $[3 ; 6]$.

Traditional building materials for pavilions were bamboo, bars and beams, stone, brick, tile and glazed tile, glaze (ceramic glaze), tree bark.

The researcher Qin Li identified the main stages of evolvement of a pavilion type to become a separate specific architectural structure, but in one chronological list he presented the stages associated with the general changes in the type of pavilion, and the construction of "iconic" pavilions in the epochs of different dynasties, which makes it difficult to draw a complete picture of the evolution of the pavilion. The stages that are more general are more important to our study, so from the whole chronological list we will highlight the following, not related to the construction of specific structures [4, 92-95]:

1) $1066-221 \mathrm{BC}$ - the first mention of the early military pavilions (Zhou dynasty);

2) $206 \mathrm{BC}-220 \mathrm{AD}$ - complication of the design scheme, the appearance of administrative, street, city pavilions and pavilions with the flag over the city gates (Han dynasty);

3) $265 \mathrm{AD}-439 \mathrm{AD}$ - appearance of decorated pavilions (Jin dynasty);

4) 420-589 AD - appearance of first landscape pavilions (the period of Southern and Northern dynasties);

5) 618-907 $\mathrm{AD}$ - distribution of pavilions in private gardens (Tang dynasty);

6) $963 \mathrm{AD}$ - mention of the oldest pavilion on the bridge (Song dynasty);

7) 1046 and 1097-1100 AD - appearance of first treatises on the construction of pavilions (Song dynasty);

8) $1634 \mathrm{AD}$ - appearance of specialized treatises on the rules for the construction of landscape pavilions. 


\section{Functional purpose of the pavilions, urban location and compositional construction}

The function of pavilions gradually evolved, diversified and became complicated from a purely strategic military function to an administrative, cult, representational, memorial and recreational one. In Ancient China, pavilions were constructed according to their functions - military pavilions occupied strategic places; roadside pavilions, street pavilions and pavilions on bridges gave short rest and protection from the sun, rain and snow. In religious ceremonies, ritual pavilions, pavilions for the sacrifice for deities, memorial pavilions in honor of rulers or religious figures were formed, in the secular life - pavilions for drinking tea, so-called "tea houses", pavilions for music classes, receiving guests, meditating and more. In parallel with the variety of functions the appearance of the pavilion evolved, which turned into a sophisticated original lavishly decorated building, harmoniously integrated into the natural environment. The increase in the number of functions has led to the construction of more pavilions, of which there are twelve in the Imperial Garden of the Forbidden City in Beijing has; five pavilions of different styles adorn Changyan Garden in Suzhou [4, 5].

Pavilions were constructed either in strategically important places (for military purposes), or in important city precincts (for administrative or public function), or in monasteries (for ritual purposes), or in a landscape setting (for aesthetic enjoyment).

Based on the existing measurement drawings, 14 pavilions of different regions of China were analyzed in terms of their compositional construction in order to establish possible proportional and metro-rhythmic patterns (Fig. 3).

These pavilions represent three main types: type 1 is horizontally elongated, with a width to height ratio of 1:0.5, type 2 is close to a square with a width to height ratio of $1: 1$, and type 3 is vertically elongated, with a width to height ratio of approximately $1: 2$. These objects are quantified as follows: type $1-2$ objects, type $2-10$ objects, type $3-2$ objects. Although these pavilions do not limit the entire list of possible forms and compositional techniques, it can be suggested that with the loss of strategic function by most of pavilions, the need disappeared to construct them tiered, such as pagodas; the presence of a large number of tiers was uncharacteristic of garden pavilions; roofs were mostly one-layered, however, their form was bizarre, with emphasis on decoration.

It was proved that there were no common proportional or metro-rhythmic patterns for the construction of such pavilions, although there were probably typical objects. Each of the examined pavilions has its own construction, which is noticeable even in the following types:

$1^{\text {st }}$ type (Fig. 4) - the height of the pavilion from the ground to the end of the roof is divided into three equal parts, which fix the bottom of the bar for binding the upper perimeter of the supports, the middle of the roof, the top of the roof without sculptural cap, the width of the pavilion between the outer sides of the extreme posts is equal to the height of the bottom of the bar for binding the upper perimeter of the supports to the top of the figured cap.

$2^{\text {nd }}$ type (Fig. 5) - the height of the pavilion from the level of the floor to the figured cap of the roof is divided in two, and the middle fixes the bottom of the bar for binding the upper perimeter of the supports and the top of the slot, this height is equal to the radius of the circle drawn from the lower inner corner of the pillar-support to the figured part of the eaves and the ball of figured cap on the roof.

$3^{\text {rd }}$ type (Fig. 6) - the height from floor level to level of stub of tile is equal to the height from the bottom of the bar for binding the upper perimeter of the supports to the top of the figure on the roof; the circles, section of circles, with radiuses from the lower inner corners of the posts to opposite corners of aperture fix the middle of the roof; if the pavilion were fit to the rectangle, the intersection of diagonals would fix the level of the stub of the bottom row of tile.

$4^{\text {th }}$ type (Fig. 7) - the whole height from the floor level to the top of the roof "horns" is divided in two, the middle fixes the top of the slot, the width between the posts is equal to the height from the floor level to the bottom of the roof, the intersection with the roof level of two circles with radiuses from the lower inner corners of the posts to the upper inner corners of the opposite posts defines the beginning of the angular details of the eaves; if the pavilion were fit to the square, the intersection of diagonals would fix the level of the top of the slot.

$5^{\text {th }}$ type (Fig. 8) - the height from the floor level to the top of the roof without the figured cap is divided in two, the middle fixes the bottom of the bar for binding the upper perimeter of supports; if the pavilion were fit to the square, the intersection of diagonals would fix the level of the stub of the bottom row of tile.

Historical pavilions of China differ in plan form, they are square in plan, round (Biluo Pavilion in Qianlong Garden of the Forbidden City in Beijing), hexa- and octagonal, paired as two cross circles (Shuanghuan Pavilion in Beijing) or two united hexagons (Taiyu Pavilion in Anhui Province), with the unmatched outlines of the lower and upper tiers (Nostalgia Pavilion in Sichuan Province). 


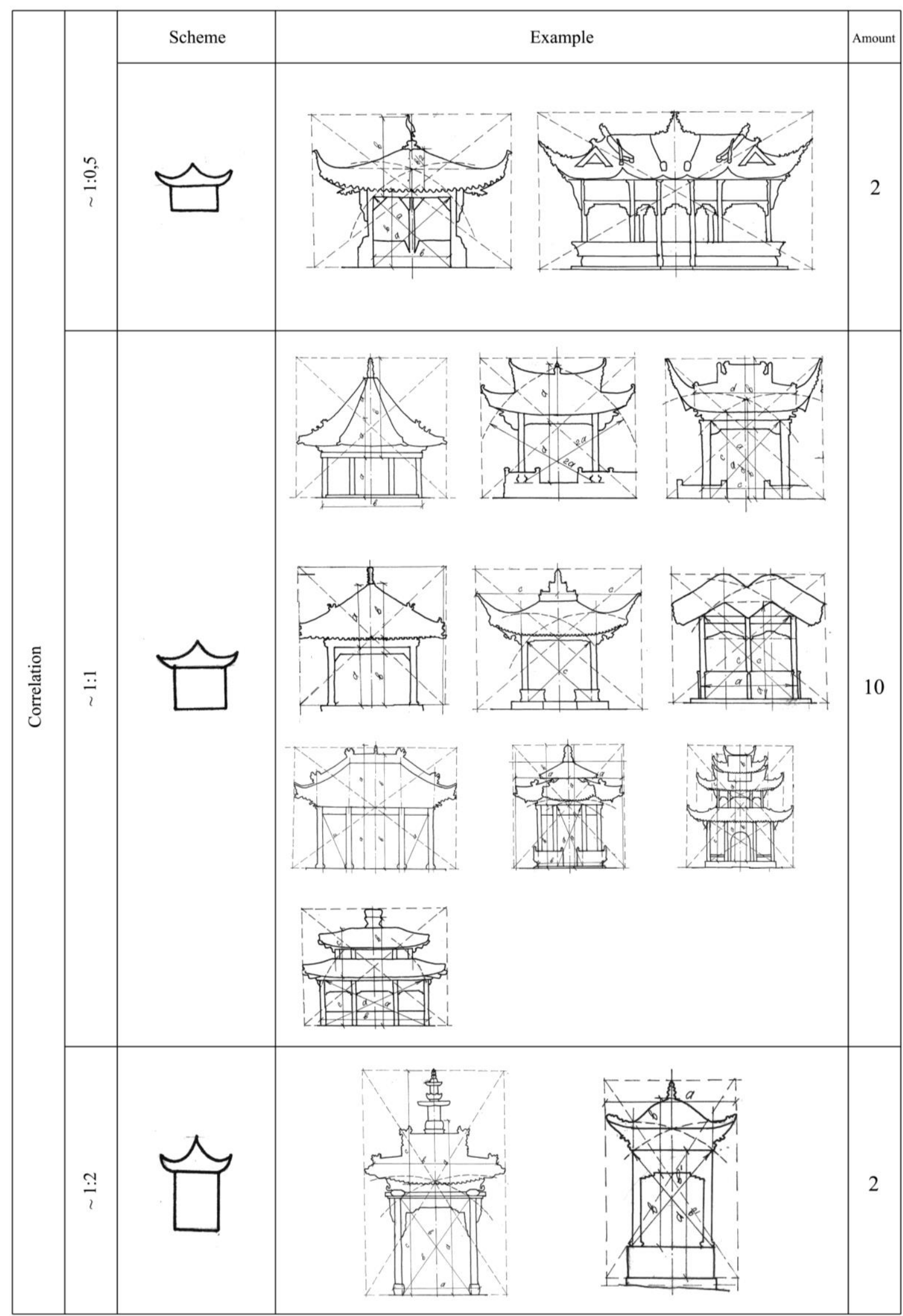

Fig. 3. Analysis of proportional and metro-rhythmic construction of historical pavilions based on dimensional drawings. Drawings by Chang Peng, 2019. 


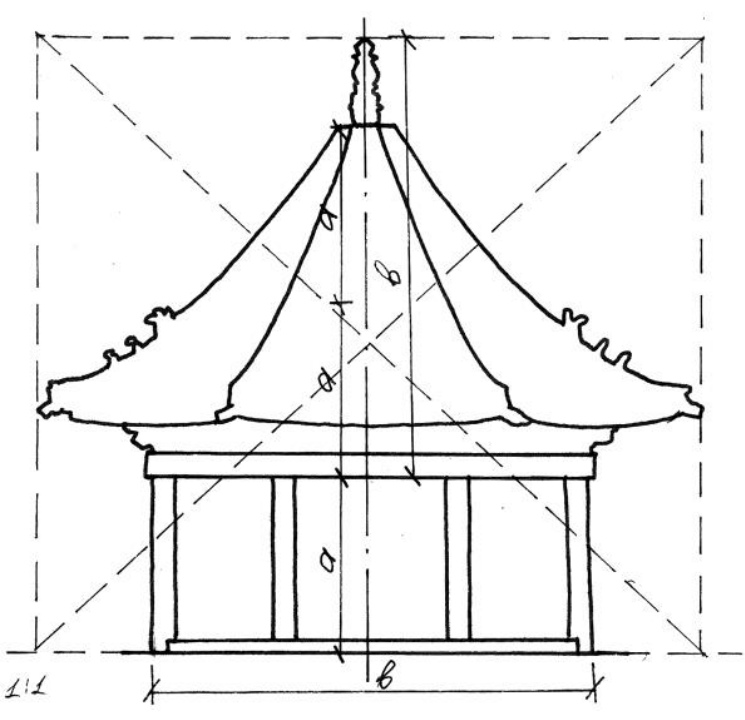

Fig. 4. Nanlao Spring Pavilion of Jinci Temple, Taiyuan, Shanxi Province. Drawings by Chang Peng, 2019.

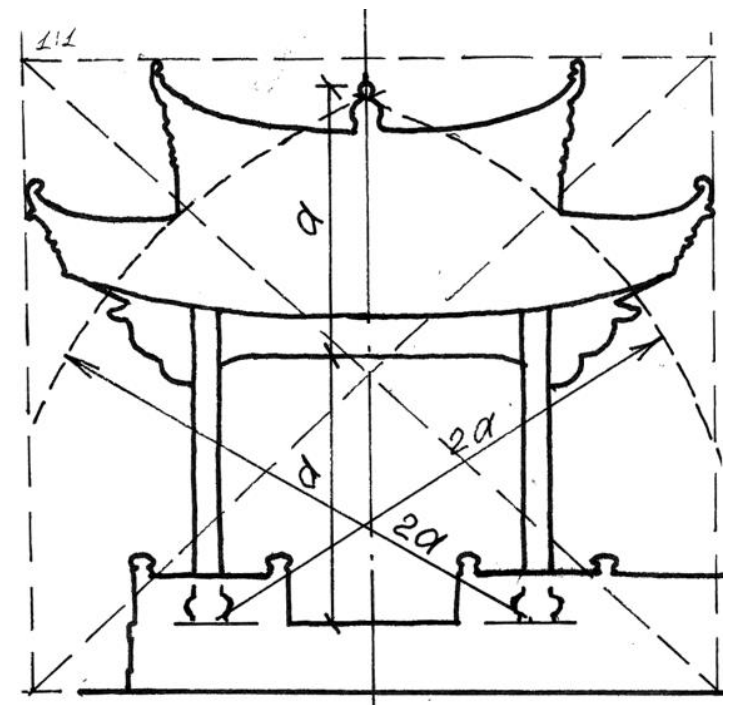

Fig. 5. Square Pavilion, Puzhao Temple in Southern Putuo of Xiamen, Fujian Province. Drawings by Chang Peng, 2019.

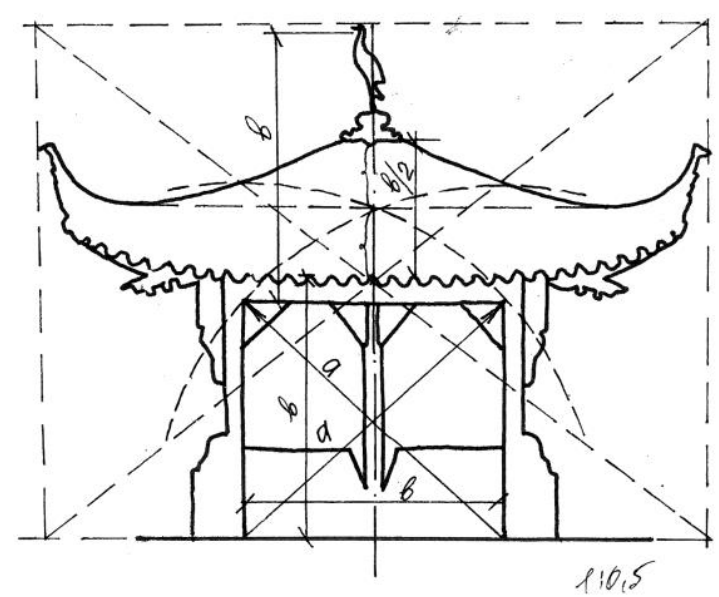

Fig. 6. Kaiwang Pavilion, Lesser Yingzhou, Hangzhou West Lake, Zhejiang Province. Drawings by Chang Peng, 2019.

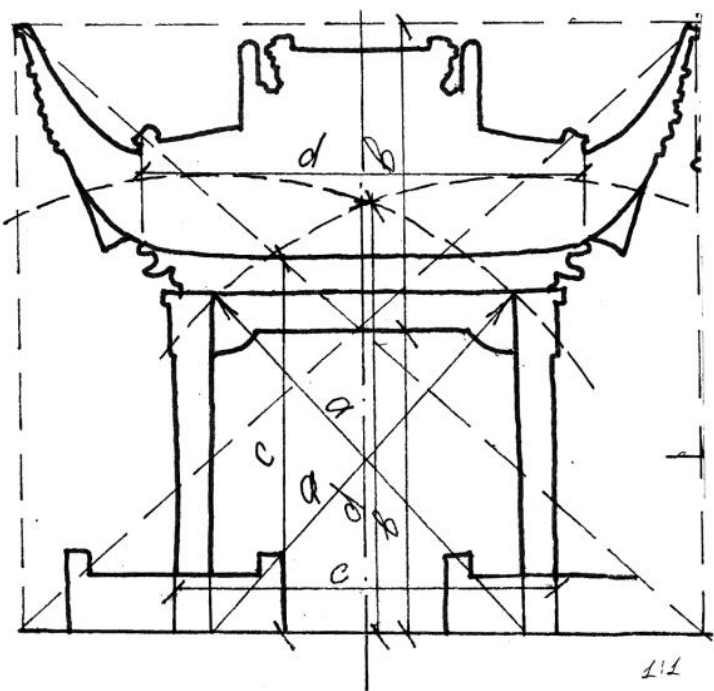

Fig. 7. The Pavilion of Surging Waves, Suzhou, Jiangsu Province. Drawings by Chang Peng, 2019.

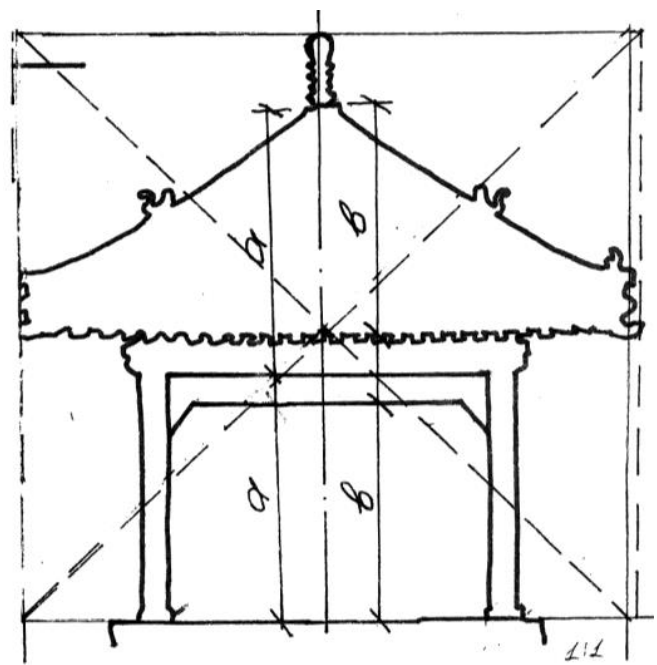

Fig. 8. Guanlan Pavilion of Baotu Spring, Jinan, Shandong Province. Drawings by Chang Peng, 2019.

\section{Types of roofs}

The most characteristic feature of Chinese pavilions is the roofs of the original outline (Fig. 9-11). Based on the analysis of samples of historical pavilions of periods of different dynasties and different functional purposes in the north, northeast, east, southwest and central China, six major types have been identified, which in turn form a significant number of modifications.

It has been found that paired roofs are found in pavilions of the northeast, in the east and less frequently in the center and in the southwest, there are types of expressively bent upward "horns" of roofs that are not typical of the north and northeast of China. The type of two-tier pavilion has not become widespread; such pavilions are found in the northeast, rarely - in the southwest and in the center. 


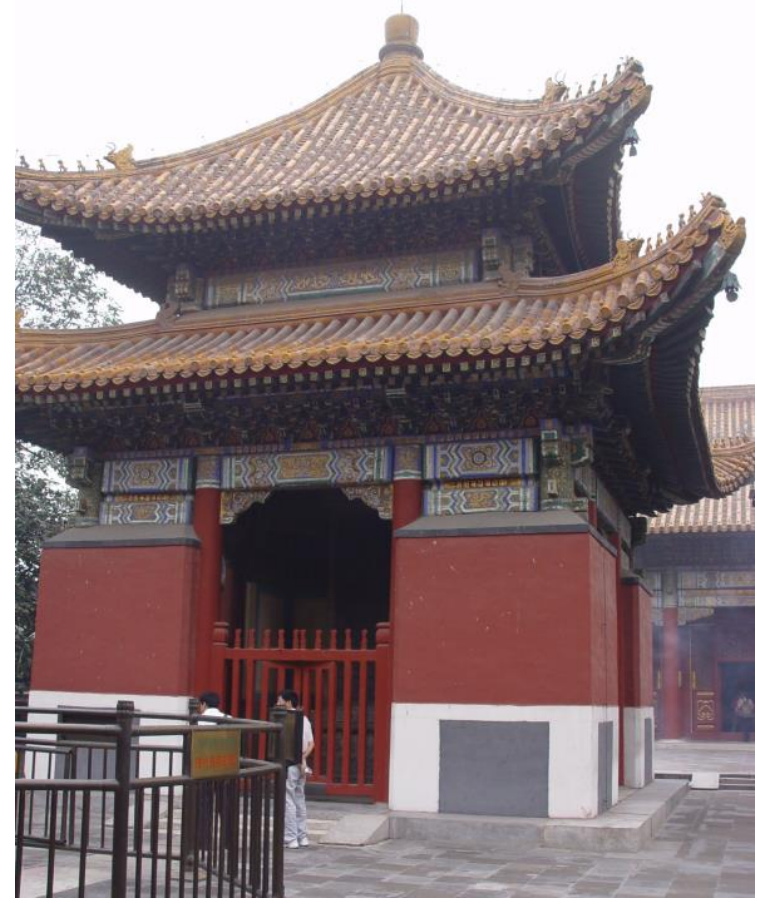

Fig. 9. Pavilion at the Gùgōng Palace in Beijing (2 ${ }^{\text {nd }}$ type). Photo by Dominika Kuśnierz-Krupa, 2017.

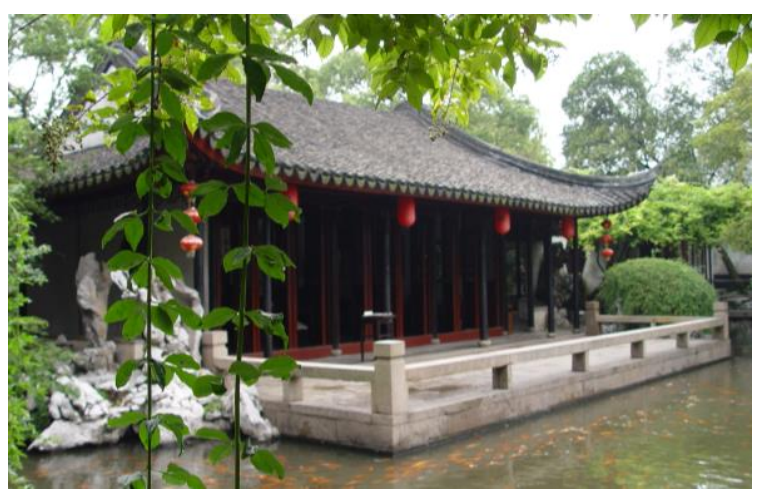

Fig. 10. Pavilion in Yu Yuan Gardens in Shanghai (1 $1^{\text {st }}$ type). Photo by Dominika Kusznierz-Krupa, 2017.

Roofs were traditional four-slope (one- and twotier), four-slope with bent up ends (one-, two- and three-tier), in the form of a tent with curved faces on an orthogonal plane, in the form of a cut tent with bent upward ends on a hexagonal plan, semi-gable, conical, with a combination of several types of roofs, and pavilions themselves were one, two- and three-tier.

Significantly, in the scientific literature, all such structures are called "pavilion", although in fact there are both closed and partially closed pavilions, and open gazebos on pillars (Fig. 9-11). The question of the origin of roof shapes in different parts of China requires additional research; for this purpose it is necessary to compare the natural and climatic conditions and cultural traditions of the regions, their mutual influences and their causes, to trace the dynamics of changes of forms and structures and decor from dynasty to dynasty.

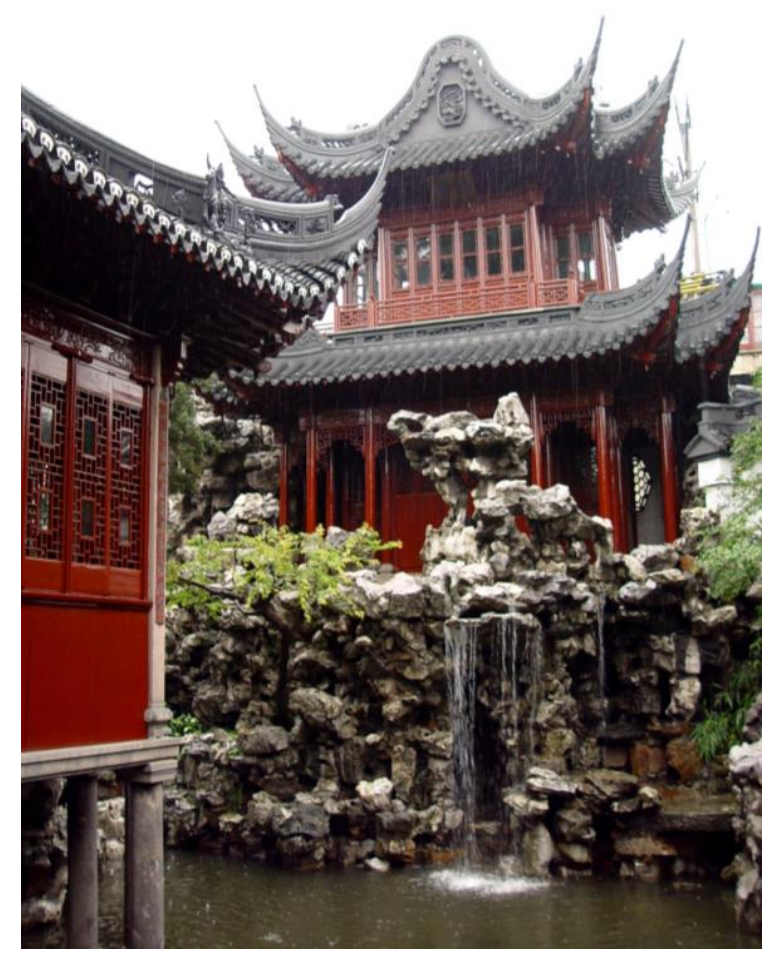

Fig. 11. Pavilion in Yu Yuan Gardens in Shanghai (2nd type). Photo by Dominika Kusznierz-Krupa, 2017.

\section{General conclusions}

The analysis of composite construction, planning, and functional organization shows that during its existence a pavilion has evolved from a simple military structure for strategic purposes to a multifunctional building, diverse in design and artistic solution of the structure, which has become one of the most massive types of buildings throughout the territory of China and a major element of landscape design $[3 ; 5 ; 6]$. Treatises gradually appeared describing the rules of construction and design of pavilions, that is, in the course of the evolution of this type of architectural building, theoretical foundations were laid under practical construction.

Contemporary Chinese-style gazebos in countries outside China cannot be considered analogues of ancient Chinese pavilions, since they are much simpler in artistic images, decor, perform a much smaller list of functions, and reduce to new materials and construction technologies [13]. 


\section{References}

1. Akhmetshin, N. Kh. Travels in China. Moscow: Ast: Vostok-Zapad, 2007.

2. Belova, Ye.Yu. (Collector). The World of Chinese culture: bibliographical reference. Vladivostok: PKPL named after A. M. Gorkii, 2007. P. 189-190.

3. Bohm A., Zachariasz A. Landscape architecture and art of gardening. The illustrated English-Polish dictionary (k-q). KOBiDZ. Warszawa 2005.

4. Chinese pavilions. Text and photos by Qin Li. China Architecture and Building Press, 2019. p. 3-96.

5. Corradini, P. Zakazane miasto. Hisoria i zbiory sztuki. Arkady. Warszawa 1999. p. 14-43.

6. Hobhouse P. Historia ogrodów. Arkady. Warszawa 2005. p. 319-434.

7. Kogan, D. R. 2007: Ancient China (encyclopedia). Transl. from English by R. Kogan. Moscow: Mir Knigi, 2007.

8. Kolpakova, A. V. Ancient China. Moscow: Belyi Gorod, 2006.

9. Kolpakova, A. V. China. Moscow: Belyi Gorod, 2006.

10. Lou, C. 10 etudes on Chinese architecture. Moscow: Publishing House of Construction Universities Association, 2009.

11. Thinkers of the Ancient and Medieval China. Moscow: Ast, 2005.

12. Vlasov, V. Chinoiserie. New Encyclopedic Dictionary of Fine Arts. In 10 vol. Saint-Peterburg: Azbuka-Klassika. Vol. X, 2010. p. 564-567.

13. Chinese-style: gazebo with original roof [electronic resource]: URL: https://nasha-besedka.ru/dizajn/stilevyenapravleniya/120-v-kitajskom-stile-besedka (access date 26.10.2019).

\section{AUTHORS:}

Yuliia Vadymivna Ivashko. A historian of architecture and landscape architect. Doctor of Architecture (2013), Professor (2015), Professor, Nostrified doctor habilitatus (2018) Kyiv National University of Construction and Architecture, 31, Povitroflotskyi Avenue, Kyiv, Ukraine.

E-mail: yulia-ivashko@ukr.net

Chang Peng, Post-graduate student, Kyiv National University of Construction and Architecture, 31, Povitroflotskyi Avenue, Kyiv, Ukraine.

E-mail: changpeng2277@gmail.com

Dominika Kuśnierz-Krupa. Architect and Landscape Architect. Doctor of Engineering (Architecture, 2010), Associate Professor at the Faculty of Architecture (2015), Head of the Chair of History of Architecture, Urban Design and Art (2018), Cracow University of Technology; Podchorążych Street no 1, Cracow, Poland. E-mail: dkusnierz-krupa@pk.edu.pl

Kopsavilkums. Rakstā tiek analizētas arhitektūras mazās formas, kas attiecās uz Ķīnas paviljoniem, to proporcijām un mērogu ainavtelpā. Izpētīta informācija par Ķīnas paviljonu pirmsākumiem. Analizēti funkcionālie un mākslinieciski figurālie paṇēmieni. Rezultātā, pētījumā tika noteikta paviljonu funkcionālā un mākslinieciski figurālā risinājuma evolūcija no dinastijas uz dinastiju. Balstoties uz saglabāto paviljonu izmēriem, tika noteiktas to proporcionālās un ritmiskās iezīmes. Izveidots un apkopots raksturīgāko jumtu formu saraksts, kas ietver Ķīnas paviljonu nacionālās oriǵinalitātes eksponentus. Pētījumā analizēti paviljonu nozīme un tradīciju atjaunošanas iemesli, kas iezīmē noteiktu stilu mūsdienīgā ainavu arhitektūras dizainā. 